This item was submitted to Loughborough's Research Repository by the author.

Items in Figshare are protected by copyright, with all rights reserved, unless otherwise indicated.

\title{
Extreme events, organizations and the politics of strategic decision making
}

PLEASE CITE THE PUBLISHED VERSION

http://dx.doi.org/10.1108/09513571011054945

PUBLISHER

(c) Emerald Group Publishing Limited

VERSION

AM (Accepted Manuscript)

LICENCE

CC BY-NC-ND 4.0

REPOSITORY RECORD

Wilson, David C., Layla Branicki, Bridgette Sullivan-Taylor, and Alexander D. Wilson. 2019. "Extreme Events, Organizations and the Politics of Strategic Decision Making”. figshare. https://hdl.handle.net/2134/14752. 
This item was submitted to Loughborough's Institutional Repository (https://dspace.lboro.ac.uk/) by the author and is made available under the following Creative Commons Licence conditions.

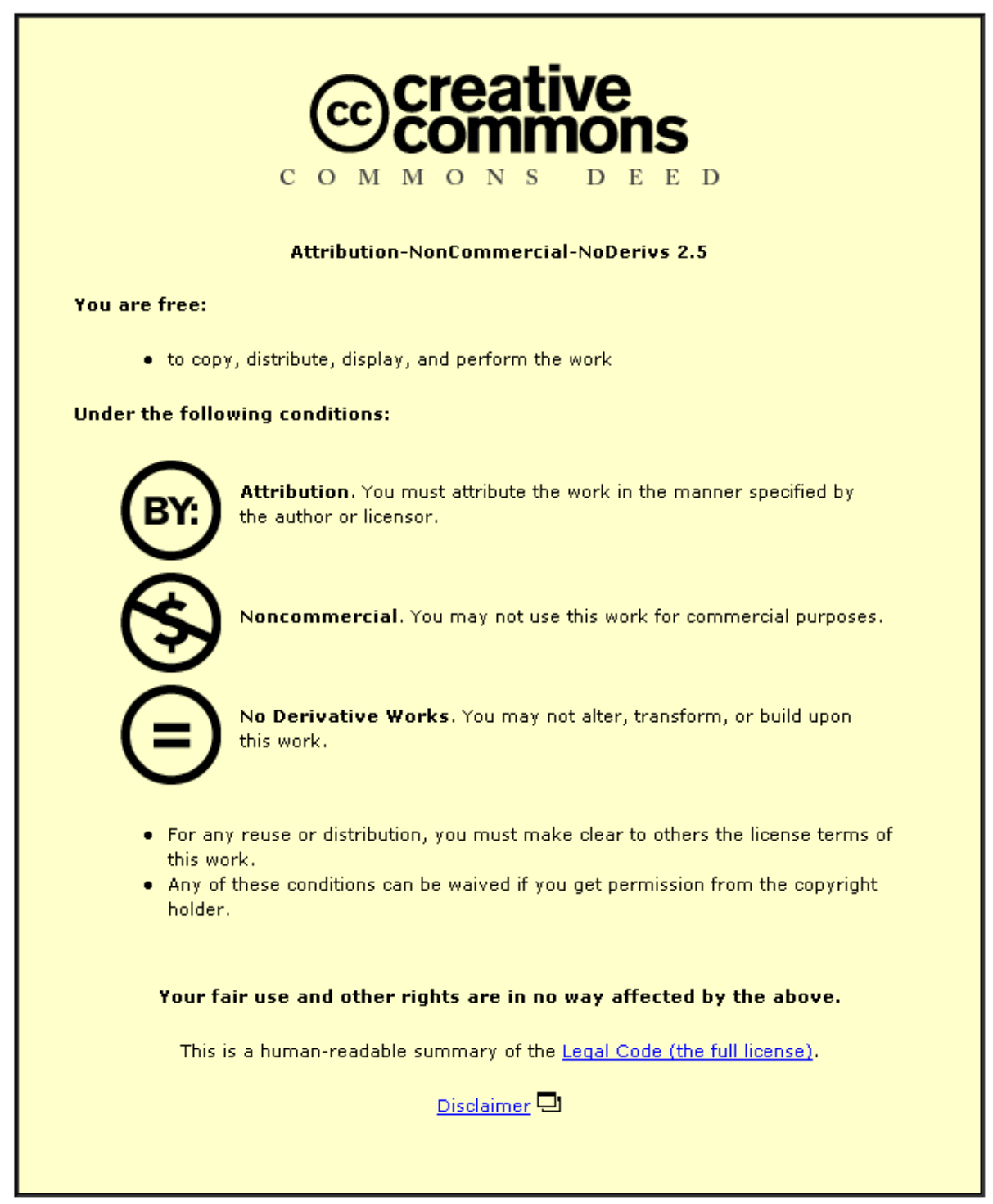

For the full text of this licence, please go to: http://creativecommons.org/licenses/by-nc-nd/2.5/ 


\title{
Extreme Events, Organizations and the Politics of Strategic Decision Making
}

\author{
By \\ David C. Wilson* \\ Layla Branicki \\ Bridgette Sullivan-Taylor \\ and \\ Alexander D. Wilson
}

This paper draws upon research supported by Leverhulme Grant no: ECF/2004/0386 and by Cabinet Office Grant no: 02078391462

*All authors are members of Warwick Business School, University of Warwick, UK. 
Extreme Events, Organizations and the Politics of Strategic Decision Making 


\begin{abstract}
Purpose - Threats of extreme events, such as terrorist attacks or infrastructure breakdown, are potentially highly disruptive events for all types of organizations. This paper takes a political perspective to power in strategic decision making and how this influences planning for extreme events.

Design/methodology/approach - A sample of one hundred and sixty informants drawn from one hundred and thirty five organizations which are part of the critical national infrastructure in the UK forms the empirical basis of this paper. Most of these organizations had publicly placed business continuity and preparedness as a strategic priority. The paper adopts a qualitative approach coding data from focus groups.
\end{abstract}

Findings - In nearly all cases there is a pre-existing dominant coalition which keeps business continuity decisions off the strategic agenda. The only exceptions to this are a handful of organizations which provide continuous production, such as some utilities, where disruption to business as usual can be readily quantified. The data reveal structural and decisional elements of the exercise of power. Structurally, the dominant coalition centralise control by ensuring that only a few functional interests participate in decision making.

Research implications - Decisional elements of power emphasise the dominance of calculative rationality where decisions are primarily made on information and arguments which can be quantified. Finally, the paper notes the recursive aspect of power relations whereby agency and structure are mutually constitutive over time. Organizational structures of control are maintained, despite the involvement of managers charged with organizational preparedness and resilience, who remain outside the dominant coalition.

Originality/value - The paper constitutes a first attempt to show how planning for emergencies fits within the strategy making process and how politically controlled this process is.

\title{
Keywords:
}

Strategic decision making, Power, Coalitions, Extreme events, Agency, Structure. 


\section{Introduction}

This paper takes a political perspective on strategic decision making in the face of extreme events. Strategic decisions are the handful of decisions which help shape what is called organizational strategy (Mintzberg et al., 1976; Hickson et al., 1986). Such decisions are likely to be planned or emergent (Mintzberg and Waters, 1985) but a common factor is that all are almost always taken in a context of risk or uncertainty. Since the future cannot be known precisely and since knowledge is imperfect, decision makers have to 'muddle through' (Lindblom, 1959) balancing actions (what they do) with what they know and do not know about a strategic (important) problem. Much of the early research on strategy and strategic decision making made two key assumptions, both turning out later to be largely unfounded (Wilson, 1992). The first was that the making of strategic decisions was an analytically rational set of activities and the second was that managerial agency had primacy in shaping what happened.

Research on risk and uncertainty revealed that the above assumptions were ill-founded. Risk describes situations in which there are measurable probabilities, whilst uncertainty refers to situations where no such probabilities can be assessed. Risk and uncertainty are, therefore, measures of the degree of ambiguity in a decision (Knight, 1921; Hertz and Thomas, 1983; Miller and Bromiley, 1990; Palmer and Wiseman 1999). All strategic decisions are taken in the context of both uncertainty and risk. Decisions are about future states of affairs and are based on incomplete information and managers therefore cannot be analytically rational in making such decisions. They also commit resources which could otherwise be used elsewhere in organizations, hence there is a large degree of opportunity cost. Putting resources into one project therefore carries with it varying degrees of risk. It might be a poor choice and jeopardize the chances of taking an alternative course of action. Following Cohen et al (1972) we argue that ambiguity in decision making provides a context in which increasingly competing and contested claims can be made from various individuals and functions in the organization. Ambiguity promotes inconsistent and ill-defined preferences throughout the organization. In addition, ambiguity forces decision makers to look to past experiences to inform current actions (to try and reduce uncertainty) and, finally, only some individuals and functions will be involved in the strategic decision making process and, hence, able to influence what happens (Cohen et al., 1972:1). Cohen and his colleagues called these decision situations "anarchic" and argue that this was the norm rather than the 
exception in strategic decision making, particularly where levels of uncertainty were relatively high (they use a decision in a University as an example).

Following Cohen et al (1972; Hickson et al 1986; Hickson et al, 2003; Miller at al., 2004:2008) it is arguable that as ambiguity facing managers and organizations increases, then so too does the propensity for organizational anarchy (and politics) to emerge. That is, preferences (priorities) are likely to be unclear and participation in the decision process is likely to involve some interests and not others. This paper examines that proposition. Data from organizations facing the threat of extreme events are used to show how (and if) organizational anarchy increases in the face of these shocks and how power is exercised by specific interests in the organization and not by others. First, we provide some contextual material concerning extreme events.

\section{Extreme Events}

Extreme events are a broad category of largely ‘exogenous jolts’ (Meyer, 1982) faced (or potentially faced) by organizations which can include 'normal accidents' such as the Bhopal explosion (Perrow, 1999), man-made disasters such as Columbia (Turner, 1976;1978), natural disasters such as the South East Asian Tsunami or Hurricane Katrina or the threat or act of terrorism (Sullivan-Taylor and Wilson, 2009). The distinction between man-made and natural disasters is not as clear as might be thought, however. Somers (2008:63) reminds us that Hurricane Katrina was as much a man-made disaster as a physical disaster, especially in the aftermath where "the world was stunned by the callous indifference and utter ineptitude of government" which exacerbated death and destruction as much as the forces of nature. But that is a topic for another paper. Energy insecurity, organized crime, pandemics and the consequences of conflicts in the world are equally examples of extreme events which organizations face (Cornish, 2007). Depending on such factors as sector and location, organizations are likely to view different events as extreme, since the local effects will be felt differentially. Farmers and food producers, for example are likely to rate an outbreak of an infectious disease amongst cattle (such as foot and mouth) very highly, whilst an energy utility is likely to give primacy to infrastructure breakdown, for example (Cornish, 2007).

Nearly all authors argue that organizations are badly designed for (and ill-prepared for) both exogenous and endogenous jolts. As a result, things go badly wrong (Anheier, 1999). For 
example, Perrow (1984) argued that one key factor is the mismatch between organizational structure and its technology in use. The explosion in the Union Carbide plant in Bhopal, India, was argued to be a result of the firm growing in size but not adapting to new technologies. When a switch was accidentally thrown, giving a false 'all systems OK' message, by the time the problem was recognized it was too late. No individual had the capacity to stop the (by now) inevitable explosion which caused long-term damage to human and plant life.

Alexander (1996) argues that the bursting of a gas pipeline in New Jersey in March 1994 was a direct result of the organizational structure of the Texas Eastern Transmission Company, which was traditional, centralized and inflexible, unable to cope with the demands of gas transmission. Greening and Johnson (1996) argue that highly interactive, tightly coupled and high-risk technologies can spell high risk in an organizational structure which is bureaucratic and inflexible. They argued that one of the problems of such organizations is the inability of top-level managers to cope with (or to prevent) disasters. Perhaps the most damning catalogue of organizational inability to cope with disasters can be found in Starbuck and Farjoun (2005) and Woods (2005) who argued that blame for the Challenger space shuttle disaster was wholly organizational in origin. Foam insulation 'strikes' (NASA terminology) caused damage to the shuttle causing it to break up on re-entry killing all on board $\left(1^{\text {st }}\right.$ February 2003). According to Woods (2005), organizational failures included the unreasonable requirement to be efficient (under time pressure) and thorough at the same time; taking past successes as indications of future performance; fragmented decision making; failure to revise estimates/actions as new evidence accumulated and poor communication between organizational sub-units.

A contrary view is taken by Weick and Sutcliffe (2001). They propose the concept of high reliability organizations (HROs) which have the capacity to prosper no matter the extent of the uncertainties it faces. Resilient companies meticulously prepare for the worst and establish routines enabling them to improvise rapid responses to crises. Weick and Sutcliffe (2001) argue that HROs exhibit mindfulness, meaning a combination of high alertness, flexibility, and adaptability which, in turn, lead to increased resilience.

The resilience perspective has had a strong influence on governments in the UK and elsewhere. In the UK, the government took action following the fuel protests and widespread 
flooding in 2000 and the foot and mouth epidemic of 2001) by way of the Civil Contingencies Act which came into force in 2004. This places duties on local authorities, emergency services etc. (known as category 1 providers) and for a range of private sector companies (known as category 2) to co-operate and share relevant information with Category 1 organizations. The act however as it stands has very little 'teeth' in that the co-operation and sharing cannot really be enforced (the act is currently under review for this reason).

This act encourages category 1 and 2 organizations to appoint managers charged with providing organizational preparedness and resilience. We refer to these generically as business continuity managers throughout this paper. Their role is to advise and talk with senior managers with regard to increasing organizational preparedness. Such appointments were meant to persuade senior managers to adopt and foster the above features of an HRO. Key decisions were expected to be made regarding organizational resilience and preparedness. A key question of this paper concerns to what extent this Act and the appointment of one or more business continuity managers were able to influence strategic decision making in UK organizations. To examine this (and related) questions we turn to the concepts of power and decision making in organizations in the following section.

\section{Theoretical Background}

Early organization theorists showed that strategic decision making was neither a wholly planned nor a rational analytical activity. For example, in an examination of the Cuban Missile’s Crisis, Allison (1969; 1971) showed how strategic decision making primarily involves many interests (in today’s jargon, 'stakeholders') who fight it out between themselves both to influence the process of the decision and its outcome so these fit as far as possible with their 'interests'. Strategic decision making is, therefore, not only complex but is also a political game played out between both personal interests and functional perspective. An organization, therefore, can be seen as an arena for decision making games (Crozier, 1964; 1976) in which a range of interests benefit (and a range do not) from particular decisions. However, all interests have an over-riding stake in the survival of the organization, so political processes are unlikely to become so acute that they fragment or seal the demise of the organization. Such 'schismatic tendencies' (Morgan, 1981) are, therefore, mostly avoided. Hence the organization remains in business providing a continuing context 
in which different interests can fight their corner to try and influence both the process and the outcome of a decision.

Such power games are, in organization theory, typically depicted as a function of resource dependencies derived from the division of labour in complex organizations. From this perspective, task specialization confers power as we have seen above (Hickson et al, 1971; Hinings et al., 1974; Pfeffer, 1981). A counter perspective argues that the given structures (from which the dependency perspectives are derived) are, in fact, the outcomes of political behaviours which have resulted in the installation of elites and regimes of control within any organization (Foucault, 1976, Clegg, 1989). It is the processes by which such control of resources and strategic contingencies become created, legitimated and sedimented in organizations which confer power. Such a perspective can be seen readily in the neoMarxist tradition (see, for example, Clegg and Dunkerley, 1980) which suggest that the creation and continuation of organizational elites who can control what happens in decision making, are simply reflective of capitalist structures more generally in which divide and rule is the norm, exercised by elites who are in control. Those who are already powerful in organizations will exercise that power by trying to influence decisions in line with their own interests of staying in power, benefitting from the outcomes of a decision and continuing to divide and rule. ${ }^{1}$

Both arguments are, in themselves, unsatisfactory since they each represent an unwavering and unchanging principle to which the foundations of power are anchored. There is also the argument that each is the subject of the other in a form of structuration of power (Giddens, 1979; 1984). That is, each is not simply a dichotomous perspective, but the one acts upon and reinforces the other in a recursive fashion over time. Some years before Giddens' depiction of structuration, the French author Karpik (1972) had noted similar recursive tendencies with regard to decision making. Karpik argued that what mattered most in the politics of decision making was not what came first (the division of labour or the creation of elites) but was the 'constancy of interest' across decisions over time. It was this constancy which meant that a fairly set group of interests influenced decisions in particular ways. Over time a theme would develop from these decisions which defined an organization's strategy. ${ }^{2}$

Other authors disagreed with the constancy of influence thesis arguing that Karpik's perspective on power means that power is synonymous with structure. For example, Crozier and Friedberg (1977) argue that individuals, coalitions and groups interact with one another 
against the context of the organization in what they describe as a game - an 'ensemble de jeux'. There are no fixed structures or dependencies which will apply in all cases of decision making (they argued). The powerful in one decision could become the powerless in a subsequent decision. Daudi (1986) shows this phenomenon in action in a detailed case study, although he does argue later in his book that interdependencies between interests in organizations may have a more enduring quality than the power game perspective (or his case study) would suggest. In other words, power constellations can persist unchanged across a number of decisions.

Empirical support for this view of relatively enduring power is provided by Miller et al (2008). In a study of 55 strategic decisions across public and private sector organizations, they found an enduring pattern of involvement and influence over decisions (in both formulation and implementation). In decision-making (formulation), the four key most involved functions (Marketing, Finance, P/SD and Suppliers), plus the CEO, emerged as the most influential. They are joined by Purchasing, R \& D and Shareholders/Auditors who, though not involved as frequently, have an influential voice in decision-making when called in.

In implementation, R \& D remains influential as do Marketing, P/SD and Finance. Suppliers, however, lose much of their influence as might be expected when the details of implementation become the responsibility of other functions inside the organization. The influence of Purchasing also disappears almost completely when it comes to implementation. Those who are less involved overall tend to have lower influence.

We argue that the dominance of the above interests as powerful and influential players in the decision power game is no accident. Each of the interests brings a strong element of calculative rationality to the decision process. We view calculative rationality as a series of institutionalised patterns of counting, accounting and measurement typically geared toward efficiency either for profit on behalf of shareholders or to deliver best value for stakeholders. As Miller et al (2008) found, the CEO, Finance, Marketing and delivery of goods or services were key players, all characterised by a strong adherence and utilisation of what could be measured, calculated and presented as a seemingly rational 'account' of desired actions in the decision process. For example, institutionalised practices of calculability such as accounting are a pervasive and powerful currency in maintaining the 'rational' state of organizations. As a technology of government and power, the calculable practice of management accountancy 
offers “...the ability to translate diverse and complex processes into a single financial figure" (Miller 2001; 381). This has been a central feature of organization since the genesis of managerialism (Chandler, 1977; Hoskin and Macve, 1994) a product of Weberian rational bureaucracy. The processes of strategic and operational planning are interwoven with the tenets of management accounting “...encompassing a growing body of techniques which have been developed in light of the needs which management have to plan, control and make decisions” (Roslender, 1992; 135).

The distinction between rational and non-rational strategies for dealing with risk (Zinn, 2008) confirms that organizations typically will engage in the calculative processes of weighing the pros and cons and providing and insuring against extreme events (see Table 1). Accounting underpins the rational organization by providing the rational measures, calculations and projections used by managers to make strategic decisions (Carruthers, 1995). We therefore suggest that, as uncertainties increase in decision making (in the context of being prepared for extreme events), it is likely that decision participants will demand and seek evidence and information which conforms to this calculative rationality.

Table 1. Orthodox contradiction of rational and non-rational strategies.

\begin{tabular}{lll}
\hline $\begin{array}{l}\text { Managing risk and uncertainty } \\
\text { by... }\end{array}$ & $\begin{array}{l}\text { Rational strategies such as... } \\
\text { Weighing of pros and cons, } \\
\text { calculation }\end{array}$ & $\begin{array}{l}\text { Non-rational strategies such } \\
\text { as... } \\
\text { Belief, hope, faith }\end{array}$ \\
$\begin{array}{ll}\text { Managing possible negative } \\
\text { outcomes by... }\end{array}$ & Provision, insurance & avoidance \\
\hline
\end{tabular}

(Adapted from Zinn, 2008; 440)

On the other hand, organizations are not static, unchanging, monoliths. The very scope and scale of the responses reflected in our own dataset on preparedness for extreme events alongside other powerful and high-profile social discourses such as global warming, binge drinking, sustainability and carbon neutrality all signal changes in the competitive operating environment and may instigate organizational changes. Such opposing views raise a set of key questions regarding power and decision making. To what extent is there continuity in the composition (and influence) of the dominant coalition in the face of extreme events? 
These issues can be summarised as a set of propositions and a key question which are addressed in this paper, namely:

\section{Propositions}

There will be strong tendencies for the dominant power constellation in an organization to remain unchanged as the key influence over all strategic decisions including decisions over extreme events.

Organizations in categories 1 and 2 will have appointed one or more senior managers to deal with continuity (and to exercise influence) in the face of extreme events to increase levels of preparedness for and responses to extreme events.

\section{Key Question}

To what extent does the appointment of new business continuity managers and the pressures to adopt high reliability organizational characteristics alter the balance of power in relation to strategic decisions concerning organizational preparedness? Does the composition and constitution of the dominant power constellation change or remain constant?

First, we provide some details of sample, method and research design adopted in this study.

\section{Sample}

Eleven focus groups were conducted across the UK on the subject of Organizational Resilience to extreme events. The groups comprised one hundred and sixty-one senior level managers drawn from one hundred and thirty five organizations situated across the public, private and voluntary sectors. The groups examined strategic decision making, resilience and contingency planning for conditions of extreme uncertainty.

The research took a theoretical approach to the sampling and the organizations selected for inclusion in this stage of the study were adapted from a range of possible targets for terrorist attack as identified by Cornish (2007) (see Table 2). Organizations were selected on the basis that they were part of the Critical National Infrastructure (CNI), supported the CNI or played a role in the normal every day functioning of society (e.g. clean water supply). This approach was informed by a pilot study (see Sullivan-Taylor and Wilson, 2009). This framework produced a sample of 135 organizations from the public and private sector, including 
National and Regional Government, Multinationals and Small to Medium Enterprises (SMEs).

Table 2: Overview of Key Sectors (adapted from Cornish, 2007)

\begin{tabular}{|l|l|l|}
\hline & Description of Sector & Example Organizations \\
\hline $\mathbf{1 .}$ & Strategic & $\begin{array}{l}\text { Utilities, Nuclear power stations, pharmaceutical factories, } \\
\text { Houses of Parliament, government and military key points }\end{array}$ \\
\hline 2. & Transport infrastructure & Road tunnels, airports, docks and railway networks \\
\hline 3. & Economic lifeline & Banking and financial institutions and areas \\
\hline 4. & $\begin{array}{l}\text { Communications } \\
\text { infrastructure }\end{array}$ & Media and broadcast organizations \\
\hline 5. & Computer network & Computing systems vulnerable to software attack \\
\hline 6. & Soft targets & $\begin{array}{l}\text { Hotels, apartment blocks, shopping malls, sports stadiums, } \\
\text { high street cafes }\end{array}$ \\
\hline 7. & Postcard targets & The Tower of London, the Millennium Wheel, Stonehenge \\
\hline 8. & $\begin{array}{l}\text { Small and Medium } \\
\text { Enterprises }\end{array}$ & Including networks representing SME communities \\
\hline
\end{tabular}

A number of key networks including the Confederation of British Industry ${ }^{3}$ and local and regional government resilience networks and fora were used to identify and to invite participants to attend the focus groups. The involvement of these network organizations is integral to the research design. Typically, the practice and effects of strategic decision making occur within delineated bounds of an organization however, the construction and communication of 'risk' and 'preparedness' used to make these decisions lie outside of conventional organizational boundaries. The key networks were employed to build a theoretical sample (Glaser, Strauss et al. 1968; Strauss and Corbin, 1998). Using the key sectors identified in Table 2, strategic decision makers were invited to participate in the research.

Table 3 gives an example of the composition of a typical focus group. This gives a range of the key UK senior representatives from target organizations in our sample. In terms of organizational job role and hierarchical level, participants of the focus ranged from business continuity, risk or security managers to Directors and Chairman. The focus groups were 
oversubscribed demonstrating the high level of interest from a range of stakeholders in this area of emerging policy and practice.

Table 3: Example of Focus Group Composition

\begin{tabular}{|l|l|}
\hline Organizational Role of Participant & Organization \\
\hline Acting Managing Director & Transport infrastructure (private sector) \\
\hline Head of Corporate Affairs & Transport infrastructure (private sector) \\
\hline Corporate Director & Regional Development Agency \\
\hline Regional Director & Corporate network \\
\hline Chairman & Transport infrastructure (private sector) \\
\hline Acting Head of Regional Resilience & Regional Government \\
\hline Partner & Computer network \\
\hline Regional Operations Manager & Transport infrastructure (public sector) \\
\hline Head of Large Corporate Team & Economic lifeline \\
\hline Director & Farmers' Union \\
\hline Business Resilience Manager & Strategic (utility) \\
\hline Director , Commercial \& Hazardous Waste & Strategic (utility) \\
\hline Chairman & Regional Enterprise Board \\
\hline
\end{tabular}

Focus groups were taped to enable the transcription and codification of the data. In addition, open-ended data from workbooks was inputted to a tailor made online database in order to capture the data and its transfer in electronic form. The focus group transcripts and the workbook database were then imported to NVivo. The analysis took the form of an interpretive thematic coding, drawing on elements of both content analysis and grounded theory (Glaser and Strauss, 1968). This approach was taken to safeguard against being overwhelmed by the data or destroying its meaning through over-intensive coding (Eisenhardt, 1999: 137). To maintain the integrity of the original texts several readings of the data were undertaken independently by the authors to identify common and enduring themes. There was substantial agreement over broad key themes. Two broad themes emerged focussing on the politicisation of decision making about extreme events. One theme from the 
data was the quantification of risk, where quantification appeared to be a necessary factor in order to get risks from extreme events on to the strategic agenda (Hoskin, 1996). Espeland and Sauder (2007) describe this as a process of commensuration, whereby qualitative phenomena are turned into quantitative in order to gain both perceived validity and attention by decision makers. A second broad theme was the constant composition and dominance over decision making of the dominant power constellation despite the appointment of new managers to oversee and make decisions about business continuity. The data were analysed around these two core themes using keywords to interrogate the data in vivo, maintaining the original form of the responses.

\section{Findings and Analysis}

\section{Defining Extreme Events}

The variety of extreme events, as described by participant organizations, is wide, reinforcing the notion that these events are predominantly subjectively defined (see Appendix A). Nevertheless, a common feature of all these depictions is that an extreme event is one which would disrupt the entire organization, possibly causing its downfall at worst and serious disruption at best. Specifically, we are dealing in this paper with the perceived threat of extreme events and decisions made to make contingency plans and actions should the event occur. Figure 1 depicts a schematic representation of informants' definitions and table 4 illustrates defining characteristics of extreme events. 
Figure 1. Defining Extreme Events: A Schematic Representation.

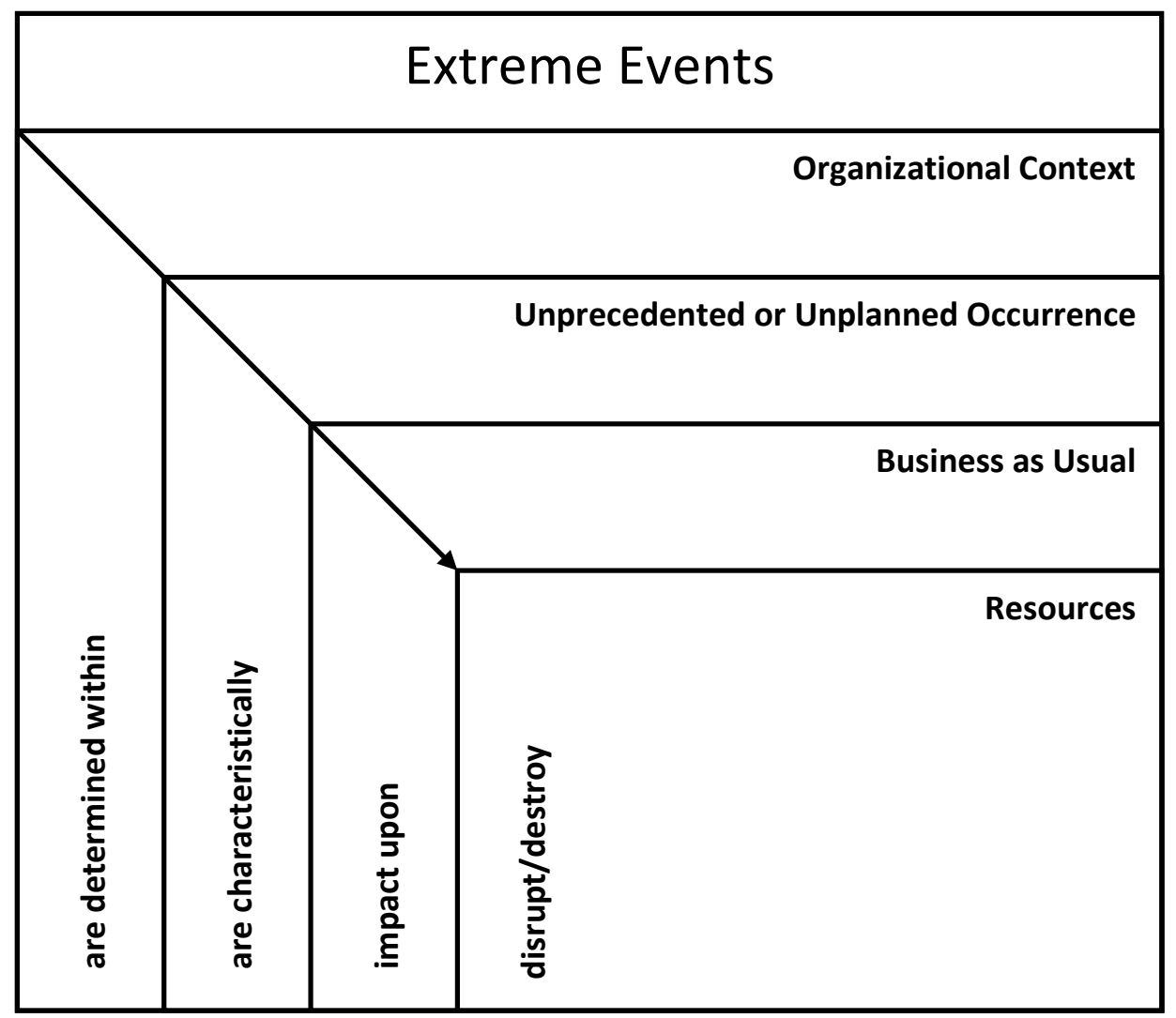

We therefore define extreme events as "determined within organizational context;

characteristically unprecedented or unplanned occurrences that impact upon business as usual through the disruption or destruction of key resources.” Table 4 illustrates some key examples from participants in the study. 
Table 4. Defining Characteristics of 'Extreme Events'.

\begin{tabular}{|c|c|}
\hline Defining Characteristic & Examples from respondents \\
\hline Organizational Context & $\begin{array}{l}\text { "Power outage at site/city. No systems on primary site. Declaration of } \\
\text { war - staff cannot come to work" } \\
\text { "unable to deliver courses and teaching to students" } \\
\text { "Contamination exposure, accidental events" } \\
\text { "Extreme weather, terrorism, security/reputation incident (denial of } \\
\text { services), total loss of utilities - power/water/telecoms" } \\
\text { "severe weather" }\end{array}$ \\
\hline Unprecedented/Unplanned & $\begin{array}{l}\text { "An extreme event would be something that is beyond the scope of } \\
\text { normal business planning - such as [a] bomb, pandemic flu, or impact } \\
\text { on utilities system.” } \\
\text { "Timing not anticipated (i.e. even if expected, don't know when) with } \\
\text { a significant impact on organization itself or on work organization } \\
\text { needs to do.” }\end{array}$ \\
\hline Business as Usual & $\begin{array}{l}\text { "An event which by its impact threatens the financial, commercial } \\
\text { stability of the organization or our ability to meet our obligations to } \\
\text { our customers." } \\
\text { "Something that will seriously affect the running of the organization." } \\
\text { "An event that has material impact upon the business, its prospects or } \\
\text { its reputation." }\end{array}$ \\
\hline Resources & $\begin{array}{l}\text { "Any event outside of normal operations that places additional } \\
\text { burdens on the organization in respect of capacity finance systems and } \\
\text { procedures." } \\
\text { "Something which cannot be dealt with using normal resources" } \\
\text { "one which overwhelms the organizations own resources (or threatens } \\
\text { to)" }\end{array}$ \\
\hline
\end{tabular}

\section{Structural Conditions of Power}

All organizations had publicly expressed their concern to make managing risks in the face of extreme events a priority (via Annual Reports, Chairman’s communications, for example). However, a strong theme emerging from the data was that the 'dominant coalition' of powerful interests who shaped decision making remained substantially an unchanging small group of senior managers who had historically controlled the strategic decision making process. Typically, this small group would comprise the CEO, the COO, the Finance 
Director and other senior managers (often Board members) and would not include the business continuity managers. This group would also neglect to consider and discuss information submitted to them by the business continuity managers and others outlining risks (we deal with the difficulty of getting discussion of extreme events on the agenda in a later section in this paper). As informants explained:

"The Board treats business continuity as a function in the organization rather than as a need to make strategic decisions" (financial services manager)

“We struggle to get buy in at senior levels” (Local authority manager)

“We don't know what goes on at senior decision making levels - we are excluded" (police force manager).

The data begin to support a structurally conditional view of power with a small, highly contingent group of senior managers either 'constricting' decision making to themselves (Hickson et al., 1986) or utilising their contingent power to keep decisions concerning extreme events off the agenda (Bachrach and Baratz, 1962; Lukes, 1974). In Clegg's (1989:97) terminology, power and authority are ‘co-aligned around the axis of legitimacy’. The most senior decision making team restricts power to decide (or not) over particular topics (such as the threat of extreme events and organizational preparedness) to a small number of senior managers and authority is vested in this small elite group. In support of Miller et al's (2008) findings we also found the composition of this elite group largely unchanging over time.

A second structural feature of power appeared related to organizational rather than authority structures. Many of the sample organizations had a central headquarters and multiple regional units' structure. Whilst the theory of high reliability organizations would suggest decentralised decision making in the regional units would be more effective than centralized decision making in dealing with high levels of uncertainty posed by extreme events, our data indicated that the majority of such organizations centralised decision making at the centre, in headquarters. For example: 
"Our HQ is in London and we're based in Birmingham, we do not have any decision makers here. They are all in London” (Financial Service manager)

“...(this creates)..the problem of us (in the regions) allowing HQ to make decisions for us” (Utility manager)

“ we have no capacity to make quick decisions which are needed...we cannot get approval for that....the organizational culture doesn't allow decision making at lower (decentralised) levels...they all need to be taken up to the board in HQ” (Rescue Services Manager)

These findings lend more support to a political view of decision making restricted to a small and centralised group (in this case the board or senior team at HQ). In this respect, our organizations present strong evidence for power being exercised in a classic Weberian sense (Weber, 1968). The hierarchical structuring of both managerial and organizational offices and their centralised relation to one another is strong evidence for this interpretation.

As Brunsson and Olsen (1993:36) argue, such centralisation is likely to lead to an information (or knowledge) gap in which "insufficient attention (is given) to local knowledge and local needs for specialization and adaption”. Our data point to this being a key issue across the sample organizations:

“...that knowledge existed within the organization but I know as a matter of fact that it was not acted upon or considered by senior managers....” (Utility manager).

"It seems very important to pick the right people in the organization to lead this type of work (decisions on preparedness and extreme events). And it is not always the senior people who are the best people at doing this. Some of the more junior people with fewer ties, more ambition and knowledge...they can be absolutely fantastic in these sorts of situations" (Financial Services manager). 
“..those people (senior managers) are making business decisions Monday to Friday... they are probably very gifted at doing this....but it takes a completely different individual trained differently and with different knowledge to be able to react to that (extreme events) environment. The structure that runs the airport Monday to Friday is not the structure that I would want to be deployed in the event of a major catastrophe" (Airport manager).

The data also point to the relatively unchanging nature of the above structural analysis of centralisation and control by a small group of senior managers. Informants indicated that decision making had always been centralised with little evidence of change, across a range of decision topics. In effect, centralised control had become institutionalised.

Such an analysis takes us from a relatively simple structural analysis of power to a more processual view, reflected in much of the recent literature in organization theory (e.g. Van de Ven and Poole, 2005; Langley, 1999; Chia and Holt, 2006). As Pajunen (2008) points out, much of the persistence of power in a small group of senior managers can be seen as evidence of organizational 'mechanisms' where the activities of practice (in this case decision making) become a stable collection of component parts which cannot be individuated. They represent institutionalised sets of actions and processes which become taken for granted and are replicated over time. This accords with Giddens' $(1979,1984)$ concept of structuration whereby the actions of agents in time one (in this cases managers making strategic decisions) become the structures and institutionalised processes of time two, where rigidities of action and involvement become fixed and often hard to change. Behaviours become fixed as routines for action (such as decision making) and associated values, interests and beliefs give meaning and reinforcement to such actions. As March and Olsen $(1984,1989)$ note, every organization has a history which in turn sediments and stabilises a whole range of processes, structures and actions. In the terms of this paper, power becomes sedimented and focussed on a small group of senior managers who control the processes and outcomes of strategic decisions. The older the organization, the more institutionalised the process of decision making becomes it seems:

"(We are) an older organization. Decision making is slow and restricted to a few senior managers. We need considerably quicker responses to crises and do things at multiple levels but it doesn't happen. For example, after the $7^{\text {th }}$ July terrorist attack in London, we had no capacity to make quick decisions and we couldn't get statements to 
the media as quickly as we would have liked” (Financial Service Organization manager)

This recursive nature of agency and structure and the build-up of institutionalised practices, leads to the second part of this analysis. In theory, the installation of business continuity managers and teams and the high levels of uncertainty inherent in preparing for extreme events should break the bounds of institutionalised practice by bringing significant change to current processes and actions. Yet our data indicate the opposite is the case. Decision making remains centralised as uncertainty and ambiguity increase:

"Such decisions are framed as investment decisions and no-one other than the senior team has any authority to decide upon investment. This goes to senior management” (Transport Infrastructure Organization manager)

Simply revealing that centralisation and control are the norm in our sample does not answer the question of possible reasons why this balance of power is maintained and reinforced. We address this question in the next section.

\section{Decisional Conditions of Power and Decision Making}

In addition to the organizational perception of extreme events, the issue of whether and how organizations prioritize avoiding or minimising elements of risk from unprecedented or unplanned events prevails. Four decision centred patterns emerged from the data. These were a) muddling through; deciding not to engage in specific business continuity planning meaning that the organization does not take pre-emptive action to prepare for extreme events; b) engaging in symbolic planning activities, but never allowing this to transcend the rhetorical domain and hence planning is not translated into practice; c) decisions continue to be made by a relatively stable set of (structurally) empowered individuals over time and that organizations perform and reproduce the (appearance) of rational forms; d) business continuity managers (and their perceived normative arguments) are viewed as disruptive to the existing power constellation not least because the accepted language of decision making 
is calculative (Power, 2007) and the basis of organizing for profit or optimal efficiency (e.g. best-value public sector orgs.). We explore these findings in turn below.

\section{a) Muddling Through}

Two quotes illustrate the range of responses one from an SME, the other from a large complex organization.

"Small businesses being prepared is not worth it. I don't have BC plan for my own business. It doesn't merit it. We are practical, we take a pragmatic view, to just muddle through. We know that, in essence, the time taken to create, maintain and review all the possibilities is quite a cost if you're not big enough and can't afford it." (Small Business Manager)

"Things happen all the time, what do we have to tell the public? The public do strange things! There's a lot of complacency, we have been here 175 years and what's the problem? We have survived bombs in WW2; we have lots of glass; lots of celebrities; it's about making the right decisions.” (Senior Manager, Exhibition and Convention Centre).

The decision to not engage in activities of risk-avoidance was seen where managers could not justify the cost of calculating risk in the first instance or second that there were so many potential risks to prepare for, it was impossible to prepare for everything. No calculation of risk could be presented. The former response was seen amongst small businesses and SMEs who saw the burden of pre-emptive action as too expensive. The latter response was seen in where there were no calculative means on which to make a decision. The de facto position was therefore to decide what to do once an extreme event had occurred, not before.

The decision to muddle through meant that in an extreme event the expectation was that the organization must be seen to make the 'right' decision as defined by the dominant coalition) and that it was the role of other agencies (e.g. local government and emergency services) to ensure a return to business as usual should an event occur.

\section{b) Engaging in symbolic decision activities}


Organizations which typically engaged in what we call symbolic decision activities manage decisions concerning extreme events by ensuring that they are treated as 'box-ticking' procedures. Typically, this comprised organizations in the health and financial services sectors (although this was not exclusive to these sectors with other organizations in the sample prone to similar symbolic activities). The power of the dominant coalition manifested itself as reducing being prepared for an extreme event to a series of checkpoints which, once ticked, indicated a high level of preparedness. Business continuity managers were seen as peripheral to this process at worst and, at best, were seen as basic administrators of a boxticking process. For example one informant in the National Health Service explained:

All you have to do is ensure you conform - you want to have ticks in all the boxes with the Department of Health. That's all that is needed. (NHS manager)

The influence of the dominant coalition in this case is predominantly characterised by being able to characterise decisions concerning extreme events as 'operational' rather than 'strategic' hence both downgrading their status in terms of organizational importance and precluding the participation of a wider set of interests in decision making (see Bachrach and Baratz, 1962; Lukes, 1974).

A related characteristic was the use of deprecatory discourse to describe business continuity. In the main, this took the form of describing such decisions as being forced on organizations as a form of externally imposed regulation. For example:

We just see business continuity as yet another burden. It is a form of regulation and no more (Financial Services Manager).

One result of such description was that senior managers in the dominant coalition tended to describe any decision making activity surrounding business continuity as problematic:

It's one big hassle (Financial Services Manager).

Again, the power of the dominant coalition is preserved and maintained by the use of such descriptions and discourse. 
Finally, some organizations had instated business continuity managers or similar roles and seemingly undertook measures to appear prepared for uncertainties. Yet this was not always the case since the dominant coalition again took charge of defining and characterising such decisions. As Carruthers (1995:318) explains, "In particular, institutional processes are routinely disguised as technical ones. Decoupling plays an important role in this process, for it allows an organization to maintain its institutionally prescribed appearances (via formal structure) without having to compromise actual operations.”

\section{c) Maintaining Structural Conditions of Power}

This emerged as a strong theme across the sample. Linked closely to some of the rhetorical and symbolic processes described above, power and influence were retained by the dominant coalition by means of a number of actions and processes. First, managers in the coalition argued along apparently rational cost or scarce resource lines. Taking decisions on preparedness involves significant costs. To justify such costs would mean an acceptance of such decisions as core business. However, as two informants argued:

Resilience benchmarks boil down to cost, how much prepared to spend. Business continuity doesn't drive business it supports it; It is down to how much cash you want to spend (Financial Services Manager)

It takes resources away from what our core business is (Transport Manager)

Secondly, such arguments were typically reinforced by discussions of profit or, more accurately, decisions about business continuity were seen as unlikely to contribute to either profit or greater organizational efficiency. For example:

That knowledge [about extreme events] existed within the organization, and that I know that as a matter of fact, but it wasn't acted upon I presume because of cost and it's been lobbied for 30 years and they refused to, because it was a profit thing. (Utility Manager).

Such processes reinforce the potency of the dominant coalition in the way theorised by Miller et al (2008) but other factors also appear to reinforce this potency when examining extreme 
events. This is because dealing with preparedness for extreme events brings with it high levels of uncertainty. An event may not happen.

It is very much a situation which might never happen; so you check as you don't want to go too far it's about striking a balance. Financial risks are nearly always considered greater importance” (Utility Manager).

These expressions reflect that extreme events (by their very nature) are uncertain. Whilst there was variation as to whether organizations presented extreme events as the unpredictable 'black swan' discussed by Taleb (2007:36) or as something more calculable and controllable, the problem of lobbying for investment on the basis of an extreme hypothetical scenario was a consistent theme. The data revealed evidence that 'established' risks were given higher priority on the decision agenda than business continuity.

"business continuity risk is looked at bi-annually whilst financial risk is looked at much more frequently” (Senior Manager: Economic Lifeline Organization).

Hypothetical scenarios dealing with predominantly endogenous shocks in the form of extreme events arguably lack the appearance of certainty and proven benefit associated with established organizational practices. In part this may be due to the inability of business continuity to frame its proposals in terms of a calculative ideal based upon numbers and economics (Power, 1997:121) as hypothetical scenarios of extreme events may fail to align to established probabilistic and cost-benefit analysis techniques.

As the Historian Hallet-Carr (1961) reminds us, the risk of identifying and prioritizing a scenario that never materializes (a 'false positive') is something which places the 'scaremongers' in a relatively power-less position and Knights et al (2008:304) in analyzing the millennium bug note that this becomes a "morally and politically loaded process":

“[extreme events].... very much might never happen; check as you don't want to go too far it's about striking a balance” (Utility Manager).

“investment when something hasn't happened (millennium bug for example) is not likely, someone made a lot of money. Do you know who to listen to, who is the expert?" 
There is arguably a professional risk for business continuity managers in predicting an extreme event which never impacts upon an organization. Despite costly preparations, failure to prioritize an extreme event which does occur (false negative) but has not been seen to be planned for may be damaging. In addition, a costly false positive (e.g. the millennium bug) could threaten to undermine future claims about the need for investment and potentially the status of business continuity managers and their equivalents as experts in their field.

Although there are difficulties with predicting extreme events business continuity managers may be reticent to present their role 'as more akin to a craft skill than a science' (Power. 1997: 121) as this may draw business continuity further away from established organizational norms at a time when "business continuity is trying to rise from the bottom" (economic lifeline business continuity manager). As discussed earlier, the data indicated that business continuity managers often lack the authority to act. Their decisions could be over-ridden and over-ruled by senior executives in the dominant coalition:

"The meddling aspect of senior executives [results in] conflict and confusion in understanding and clarifying roles, responsibility and authority to act” Economic lifeline Manager

“often work is 'wasted' as 'guts' are used (by senior managers) to decide rather than analysis" Computer Network Manager

The relative powerless-ness of business continuity managers from these perspectives is closely aligned to classic Sociological analyses of class or social stratification (see Wesolowski, 1979 for example). Taking a functional perspective to the unequal division of power, and building on the work of Parsons (1954) and Davis and Moore (1945), Wesolowski argued that functional structures such as organizations would, over time, display sharp inequalities in who (or which groups) had a strong voice in decisions over key issues and that what were defined as key issues would, in turn, be defined by stratified variations in power. From these perspectives, the roots of power lie in what are more or less defined and accepted as 'functional requirements' of organization (business as usual rather than preparedness for extreme events in the case of this paper). Somewhat ironically, Davis and Moore’s (1945) notion of 'functional necessities' (those functions needed to keep the 
organization working safely, smoothly and help growth) which were heavily criticised as being too universal by later Sociologists have re-entered today’s organizational vocabulary, albeit using different (but nonetheless universal) terminology such as 'resilience' (see Cornish, 2007).

\section{d) Business continuity and threats to established power structures in organizations.}

Unexpectedly, the data revealed that the actions of business continuity managers may be perceived not as a 'functional necessity' but as a threat to the established power structure. This seemed to be largely due to the actions of business continuity managers cross-cutting established (and often separate) organizational functions. For example, a business continuity manager from an economic lifeline organization was aware that in their role that they "had to cut across the normal organizational structure”. This was perceived by the dominant coalition as potentially threatening to their established (and functionally derived) power bases. The work of business continuity managers requires them to propose broad (sometimes universal) decisions or measures of integration in relation to other departments. Business continuity and resilience managers may, therefore, be perceived as a driver for integration which threatens established norms of departmental independence and/or specialization in organizations. As one informant described it:

" there is a problem of allowing another part of the organization to make a decision for you”. (Senior Manager, Government Agency)

Secondly, in order to plan for hypothetical scenarios (such as the evacuation of headquarters) a business continuity manager may create further threats. Such a manager may be placed in a role where they are suggesting the introduction of processes which question or transgress established organizational norms:

"any business is about making money; you don't get buy in for doing tests; don't get buy in from senior management. They are not going to let 30 people off for the afternoon”. (Senior manager: Economic lifeline). 


\section{Summary}

The data indicate that managers generate a contextually situated perception of extreme events, but a uniform understanding of extreme events is that they will affect business as usual and disrupt the resources of an organization. It is common, and in some sectors mandatory, for organizations to instate business continuity managers within the formal organizational hierarchy.

However, for issues of business continuity to make the agenda in strategic decision making (one of Lukes’ 1974 key conditions of power) the significance of extreme events appears to necessitate communicating threats and risks in calculative terms. This chimes with the findings of Hoskin and Macve (1994). The data reveal that organizations vary in their prioritisation of extreme events. Prioritisation is, however, not solely a function of power struggles to represent preparedness in the language of the dominant coalition. A small group of organizations in the study did prioritise preparedness. These were organizations operating with continuous, or near-continuous, production typically placed business continuity as an operational imperative. Because the continuity of production or functioning of the organization is so closely linked to profit and performance, some form of rational calculation is a normal practice in assessing any shocks to business as usual: In this sense these organizations engage in managing risk and uncertainty by rational strategies such as calculation of possible negative outcomes by provision and insurance (Table 1: Zinn, 2008) against extreme events.

Business continuity managers were often faced with competition for scarce resources within their organization and continuity initiatives were regularly sidelined as they were not considered part of core business activity. Business continuity initiatives are appraised against established business functions and in the context of existing power relations. These included the dislocation of business continuity from the domain of profit or efficiency. The hypothetical nature of risk and the abstracted probabilistic nature of extreme events means that other types of risk are mostly prioritised, especially those of a financial nature. The speculative tasks involved in the practices of business continuity managers often served to undermine their 'expertise'; the juxtaposed balance of preparing for something that is never seen to happen or dealing with the aftermath of an unforeseen occurrence means that the credibility of continuity management is often in flux. The measures put in place, or 
suggested, by continuity managers can be overridden by media coverage (what is the latest scare?) and the consequent gut reactions of senior managers placing continuity managers in a reactive role further distancing them from the central arena of strategic decision making.

\section{Conclusions}

Strategic and operational decisions continue to be made along calculable lines. Stratification of power in organizations is, to a large extent, maintained by what can be measured or presented in a calculative format (Hoskin and Macve, 1994).

This paper suggested that, by increasing levels of uncertainty (such as in the context of extreme events) such relatively stable stratification may be subject to change and the balance of power may tip in favour of those proposing organizational preparedness. However, the data do not support such a view. It seems that the existence of large organizational structures not only creates inequalities in power between interests or functions, but maintains them independently of levels of uncertainty.

The findings of this research reveal the position of 'resilient practices' such as business continuity to be an illegitimate logique d'action (Karpik, 1972) for UK organizations. This suggests that there is a hiatus (Meyer and Rowan 1991) between the institutionalised calculative order of strategic decision making and their business continuity practices unless the risk can be expressed in calculable terms (Power, 1992). Because the activities of business continuity managers involve assessing their own organization to propose initiatives, these can be perceived to threaten the established power balance in the organization. Where the threat of extreme events cannot be calculated, or communicated in calculable terms, business continuity managers experience ‘decoupling’ effects (Meyer and Rowan, 1991) between the organizational practice and the politics of strategic decision making. As a result, the power constellation around the dominant coalition remains unchanged.

Decisions to prepare for extreme events are often decoupled from the organizational practice of preparedness. The extant constellations of power continue to behave in a 'rational', albeit institutionally legitimate, mode of managerial calculative rationality. The culture, resources and practice of initiatives like 'business continuity' and 'disaster planning' conflict with the established 'rational' considerations of strategic and board level decisions. Hence, while organizations were often restructured to meet the needs of the Civil Contingencies Act and 
hence to address risks from extreme events, the practitioners of preparedness often experienced decoupling unless the risks are presented in quantitative discourse, illustrating a calculatively rational course of action. And even then, such decisions are given lower priority by the dominant and unchanging coalition who exerted power over the processes and outcomes of decision making.

The data presented here reveal some key insights into strategic decision making as a political activity. In particular, there is little or no evidence to support Cohen et al.'s (1972) notion of fluid participation of interests alongside conditions of high ambiguity or problematic preferences. Such anarchy (as these authors described it) appears not to be the case, at least in the highly ambiguous context of preparedness for extreme events. Rather, the structural and decisional elements of power seem to play an important role in defining, shaping and maintaining the composition of the key power constellation, the dominant coalition. The findings reveal strong tendencies of recursive concentration of decision making in the hands of a few powerful interests, which effectively precludes either business continuity managers having a voice in decision making, or having any influence over key decisions. 


\section{Endnotes}

1. There is, of course, a counter argument which suggests that the division of labour in an organization is essentially egalitarian since the division of labour and control are directed solely at the market rather than internally in organizational power struggles. From this perspective, the market (and market signals) are the key influence over decision making and not organizational elites.

2. This observation of strategy being a pattern in a stream of successive decisions was more famously developed some years later by Henry Mintzberg in his writings on strategy.

3. The premier lobbying organization for UK business on national and international issues; works with the UK government, international legislators and policymakers to help UK businesses compete effectively.

\section{Appendix A}

\section{Example Descriptions and/or Definitions of an 'extreme event'? A selection of responses from} informants.

A one off large scale widespread crisis which may or may not be unpredictable.

An effect which prohibits business functioning at $100 \%$ for a prolonged period of time more than 5 days. An event that demands a sustained response over and above the day to day working of our organization.

An event that has material impact upon the business, its prospects or its reputation.

An event that is larger than a major incident and is national or regional instead of local e.g. weather (wind, rain, snow), global, virus, oil prices etc.

An event that is so influential that normal operation becomes impossible for a period of time.

An event that requires our incident management capability to be "stood-up" as it is likely to impact on our ability to work as business as usual.

An event that significantly disrupts the normal pattern of life e.g. terrorist attack.

An event which has a severe business impact (ability to function normally is impaired) to the extent that abnormal measures are required to restore normality.

An event which stretches our ability to carry out our primary function to a level which is at or beyond our limits.

An occurrence that affects the organizations ability to carry out its essential functions. The extremity is judged by the effect.

Any event outside of normal operations that places additional burdens on the organization in respect of capacity finance systems and procedures.

Any event which requires significant deployment of resources and/ or impact on national security. 


\begin{tabular}{|c|}
\hline $\begin{array}{l}\text { Anything which is unplanned which interferes with service delivery in the everyday life in the } \\
\text { community. }\end{array}$ \\
\hline Challenges the organization beyond the bound of what it is used to / able to deal with. \\
\hline $\begin{array}{l}\text { Either the inability to provide employees with a place to carry out their work (perhaps because of a loss } \\
\text { or damage to a building) or a health or transport issue preventing attendance at work place. }\end{array}$ \\
\hline $\begin{array}{l}\text { Event that would require additional response and resources beyond standard operating procedures and } \\
\text { which may threaten the continued existence of operating. }\end{array}$ \\
\hline $\begin{array}{l}\text { It's about a personal perspective. Any event that seriously disrupts the organizations continuity does not } \\
\text { confuse major disasters such as pandemic and tsunami with this. }\end{array}$ \\
\hline $\begin{array}{l}\text { Loss of supply of water to a population of } 720,000 \text { people for more than } 24 \text { hours. Terrorism or other } \\
\text { occurrence which leads to contamination of water supplies and risk to human health }\end{array}$ \\
\hline $\begin{array}{l}\text { One that requires the organization to invoke its contingency procedures in terms of work area, data centre } \\
\text { etc. Due to not being able to operate normally you have to move into crisis management. }\end{array}$ \\
\hline $\begin{array}{l}\text { Something highly disruptive and above normal operations and something organizations feel unprepared } \\
\text { to handle. Could be one of countless scenarios but they will "know it when it HITS and HURTS them". } \\
\text { Often think in terms of physical/ environmental disasters e.g. fire, flood, rather than wider spectrum of } \\
\text { types. }\end{array}$ \\
\hline $\begin{array}{l}\text { Something that happens unexpectedly which impacts / affects the health and safety of residents / staff or } \\
\text { prevents organization from functioning - e.g. flood,/ fire/ robbery/ loss of building (collapse or explosion/ } \\
\text { death/ sabotage/ IT failure/ utilities. }\end{array}$ \\
\hline Something which cannot be dealt with using normal resources. \\
\hline $\begin{array}{l}\text { Something which stops me running a train service and threatens cash. A good example was when in } 2005 \\
\text { a tunnel collapsed on the line and blocked it for } 7 \text { weeks. This is hopefully exceptional. }\end{array}$ \\
\hline $\begin{array}{l}\text { That which appears to be above the threshold level of the ordinary day to day; will need an out of the } \\
\text { usual plan to deal with the extreme events. }\end{array}$ \\
\hline $\begin{array}{l}\text { Uncertainty - level of disruption does not have to be huge, e.g. Exeter restaurant bomb. IT breakdown } \\
\text { could cause the banking sector not to function. }\end{array}$ \\
\hline
\end{tabular}




\section{References}

Alexander, C.B. (1996) ‘Planning for disaster’, American Gas, 78, 2, $24-7$.

Allison, G.T. (1969) 'Conceptual models and the Cuban missiles crisis', American Political Science Review, LX111, 3, 689-718.

Allison, G.T. (1971) Essence of Decision, Little, Brown: Boston

Anheier H.K (Ed) (1999) When things go wrong: organizational failures and breakdowns, Sage: London.

Bachrach, P and M.S. Baratz (1962) 'The Two Faces of Power', American Political Science Review, 56, 947-52.

Brunsson, N. and J.P. Olsen (1993) The Reforming Organization, Routledge: London.

Carruthers, B. G. (1995). "Accounting, ambiguity, and the new institutionalism." Accounting, Organizations and Society 20(4): 313-328.

Chandler, A. D. (1977). The visible hand: the managerial revolution in American business.

Cambridge, Mass., Belknap Press.

Chia, R and R. Holt (2006) 'Strategy as Practical Coping: A Heideggerian Perspective', Organization Studies, 27, 2, 635-655.

Clegg, S.R. (1989) 'Radical Revisions: Power, Discipline and Organizations, Organization Studies, 10, 1, 97-115.

Clegg, S.R. and D. Dunkerley (1980) Organization Class and Control, Routledge, Kegan \& Paul: London.

Cohen, M.D., March, J.G., and J.P. Olsen (1972) 'A Garbage Can Model of Organizational Choice’, Administrative Science Quarterly, 17, 1-25.

Cornish, P. (2007) Britain and security. London: The Smith Institute.

Crozier, M. (1964) The Bureaucratic Phenomenon, Tavistock: London.

Crozier, M. (1976) 'Comparing structures and comparing games', in European

Contributions to Organization Theory, Geert Hofstede and M. Sami Kassem (Eds), 193-207 Van Goreum: Amsterdam.

Crozier, M. and E. Friedberg (1977) L’Acteur et le Systeme, Seuil: Paris.

Daudi, P. (1986) Power in the Organization: The Discourse of Power in Managerial Praxis, Blackwell: Oxford.

Davis, K. and W. Moore (1945) 'Some Principles of Stratification', American Sociological Review, 2, 24-35. 
Eisenhardt, K. Building Theories from Case Study Research. In, Bryman and Burgess (Eds.) Qualitative Research. (Pp. 135-159). London: Sage. 1999.

Espeland, W. and M. Sauder (2007) 'Rankings and Reactivity: How Public Measures Recreate Social Worlds', American Journal of Sociology, 113, 1, 1-40

Foucault, M. (1976) Discipline and Punish, Penguin: Harmondsworth.

Giddens, A. (1979). Central Problems in Social Theory. London: Macmillan.

Giddens, A. (1984). The Constitution of Society. Cambridge: Polity Press.

Glaser, B. G., Strauss, et al. (1968). The Discovery of grounded theory. Strategies for qualitative research, pp. x. 271. Weidenfeld \& Nicolson: London; printed in U.S.A.

Greening, D.W. and R.A. Johnson (1996). Do Managers and Strategies Matter? A Study in Crisis, Journal of Management Studies, 36, 25-51.

Hallett-Carr, E. (1961) What is History? Vintage: New York

Hertz, D. and Thomas, H (1983) Risk Analysis and its Applications, Wiley, New York.

Hickson, D.J., Butler, R.J., Cray, D., Mallory, G.R. and D.C. Wilson (1986) Top Decisions: Strategic Decision Making in Organizations, Jossey-Bass: California.

Hickson, D.J., Hinings, C.R., Lee, C.A., Schneck, R.E. and J.M. Pennings (1971) 'A strategic contingencies theory of intraorganizational power', Administrative Science Quarterly, 16, 2, 216-29.

Hickson, D.J., S.J. Miller, and D.C. Wilson, (2003) 'Planned or prioritized? Two options in managing the implementation of strategic decisions', Journal of Management Studies, 40, 7 201-218.

Hinings, C.R., Hickson, D.J., Pennings, J.M. and R.E. Schneck (1974) 'Structural conditions of intraorganizational power’, Administrative Science Quarterly, 19, 1, 22-44.

Hoskin, K. and R. Macve (1994). "Reappraising the Genesis of Managerialism: A Reexamination of the Role of Accounting at the Springfield Armory, 1815-1845." Accounting, Auditing \& Accountability Journal 7(2): 4-29.

Hoskin, K (1996) “The 'Awful Idea of Accountability': Inscribing People into the Measurement of Objects." in Accountability, Power, Ethos and the Technologies of Managing, edited by R. Munor and J. Mouritsen. International Thomson Business Press: London.

Karpik L. (1972) 'Les politiques et les logiques d'action de la grande enterprise industrielle', Sociologie du Travail, 1, 82-105.

Knight, F.H. (1921) Risk, Uncertainty and Profit, University of Chicago Press, Chicago. 
Knights, D., Vurdubakis, T. and H. Willmott (2008) 'The night of the bug: technology, risk and (dis) organization at the fin de siècle', Management and Organizational History, 3, 289309.

Langley, A. (1999) 'Strategies for Theorising from Process Data', Academy of Management Review, 24, 691-710.

Lindblom, C.E. (1959) 'The Science of Muddling Through', Public Administration Review xix/2 79-88.

Lukes, S. (1974) Power: A Radical View, Macmillan: London.

March J. and J.P. Olsen (1984) 'The New Institutionalism: Organizational factors in Political Life', American Political Science Review, 78, 734-749.

March J. and J.P. Olsen (1989) Rediscovering Institutions: The Organizational Basis of Politics, Free Press: New York.

Meyer, Alan D. (1982) 'Adapting to environmental jolts,' Administrative Science Quarterly, 27: 515-537.

Meyer, J. and B. Rowan (1991). Institutionalized Organizations: Formal Structure as Myth and Ceremony, in The New Institutionalism in Organizational Analysis, W. W. Powell and P. J. DiMaggio (Eds) University of Chicago Press: Chicago.

Miller, K. D. and Bromiley, P (1990) 'Strategic risk and corporate performance: an analysis of alternative risk measures’, Academy of Management Journal, 39, pp. 91-122.

Miller, P. (2001). "Governing by Numbers: Why Calculative Practices Matter." Social Research 68: 379-396.

Miller, S, Wilson, D and D Hickson (2004) 'Beyond planning: strategies for successfully implementing strategic decisions’, Long Range Planning, 37, 3, 201-218.

Miller, S., Hickson, D.J. and D.C. Wilson (2008) From Strategy to Action: Involvement and Influence in Top Level Decisions', Long Range Planning, 41 606-628.

Mintzberg, H. (1983) 'Power In and Around Organizations, Prentice-Hall: Englewod Cliffs, NJ.

Mintzberg, H. Raisinghani, D. and A. Theoret (1976) 'The structure of 'unstructured' decision processes', Administrative Science Quarterly, 21, 246-75.

Mintzberg, H and J.A. Waters (1985) 'Of Strategies, Deliberate and Emergent', Strategic Management Journal, 6, 257-272.

Morgan, G. (1981) 'The schismatic metaphor and its implications for organizational analysis', Organization Studies, 2,1, 23-44. 
Parsons, T. (1954) 'Suggestions for a Sociological Approach to the Theory of Organizations 1 and 11', Administrative Science Quarterly, 1, June and September, 63-85, 225-39.

Pajunen, K. (2008) 'The Nature of Organizational Mechanisms’, Organization Studies, 29, $11,1449-1468$.

Palmer, TB and Wiseman, RM (1999) 'Decoupling risk from income stream uncertainty: a holistic model of risk', Strategic Management Journal, 20, pp. 1037-62.

Perrow, C. (1984) Normal accidents: Living with high risk technologies. Princeton: Princeton University Press.

Pfeffer, J. (1981) Power in Organizations, Pitman: Boston.

Power, M. K. (1992). 'From Common Sense to Expertise: Reflections on the Prehistory of Audit Sampling', Accounting, Organizations and Society: 37-62.

Power, M. K. (2007). Organized Uncertainty. Designing a World of Risk Management. Oxford University Press: Oxford.

Roslender, R. (1992). Sociological perspectives on modern accountancy, Routledge: London.

Starbuck, W. and M. Farjoun (Eds) (2005) Organizations at the Limit, Blackwell: Oxford.

Somers, M.R. (2008) Genealogies of Citizenship: Markets, Statelessness and the Right to Have Rights, Cambridge University Press: Cambridge.

Strauss, A. L. and J. M. Corbin (1998). Basics of qualitative research: techniques and procedures for developing grounded theory. Thousand Oaks, Calif., Sage Publications.

Sullivan-Taylor, B. and D.C. Wilson (2009) 'Managing the Threat of Terrorism in British Travel and Leisure Organizations’, Organization Studies Volume 30 No. $2 \& 3$ (double issue).

Taleb, N. N. (2007). The Black Swan. Penguin: Harmondsworth.

Turner, B. (1976) ‘The organizational and interorganizational development of disasters’.

Administrative Science Quarterly 21/3: 378-397.

Turner, B. (1978) Man-made disasters. London: Wykeham.

Van de Ven, A. and M.S. Poole (2005) 'Alternative Approaches for Studying Organizational Change’, Organization Studies, 26, 11, 1377-1404.

Weber, M. (1968) Economy and Society: An Outline for Interpretive Sociology, Bodminster Press: New York.

Weick, Karl E.; Kathleen M. Sutcliffe (2001). Managing the Unexpected - Assuring High Performance in an Age of Complexity. San Francisco, CA,: Jossey-Bass,

Wesolowski, W. (1979) Classes, Strata and Power, Routledge \& Kegan Paul: London. 
Wilson, D.C. (1992) A Strategy of Change, Routledge: London

Woods, D.D. (2005) 'Creating foresight: Lessons for enhancing resilience from Columbia', in W. Starbuck and M. Farjoun (Eds) Organization at the limit, Blackwell: Oxford.

Zinn, J. O. (2008). "Heading into the unknown: Everyday strategies for managing risk and uncertainty." Health, Risk \& Society 10(5): 439 - 450. 